\title{
日本酒座談会一新たな日本酒ファンを増 やすにはー
}

近年国内の日本酒需要は少子高齢化の影響等もあり, 減少傾向にあります。一方, 2015 年の日本酒の輸 出金額は約 140 億円（対前年比 $121.8 \%$ ）と，4 年連続で過去最高を記録しました。

このような背景の下, 国税庁では, 日本酒業界がより活性化するためのヒントを蔵元の皆様からお伺いす るために日本酒座談会を第 52 回 (独) 酒類総合研究所講演会に併せて開催しました。

国 税 庁

日時：平成 28 年 5 月 25 日（水） $15: 50 \sim 16: 50$ 場所：東広島芸術文化ホール（くらら）2 階大ホール 登壇者

今田美穂 株式会社今田酒造本店杜氏

尾畑留美子

木下宏太郎 尾畑酒造株式会社専務取締役

佐藤祐輔

秦 洋二 株式会社喜多屋代表取締役 新政酒造株式会社代表取締役 月桂冠株式会社常務取締役兼総合研 究所長

中原 広 国税庁長官

宇都宮仁

国税庁課税部鑑定企画官 司会

田中沙百合 2016 ミス日本酒

以下，座談会部分においては敬称を省略させていた だきました。

\section{1 はじめに}

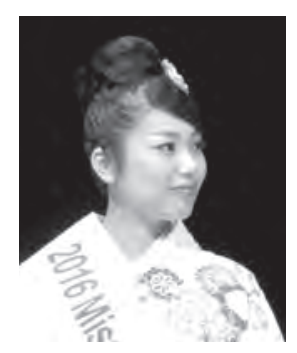

田中氏
（田中）皆様はじめまして, 2016 ミス日本酒の田中沙百合 と申します。本日はよろしくお 願いいたします。

本日は, 酒類業を所管してい る国税庁より中原長官に扮越し 頂いております。中原長官一言 ご挨拶をお願いします。

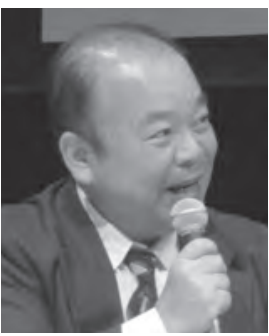

中原氏
（中原）只今，ご紹介いただき ました国税庁の中原でございま す。私ども国税庁は, 法律上 「酒類業の健全な発達」を重要 な任務の一つとしておりまして， 関係省庁と連携しながら, 酒類 業の振興に取り組んでいるとこ ろでございます。

とりわけ，私ども国税の組織には，本日主催をして おります酒類総合研究所や鑑定官といった技術分野の 専門家がおりまして, 主として技術面から酒造りに関 する支援をさせていただいているところであります。 今後も酒類業界の更なる発展に向けて, 造り手の皆さ んに頼られる国税組織でありたいと考えております。 ただ，今申しましたとおり，私どもこれまではどちら かというと技術面中心の支援を行ってきましたが，今 後はいろいろな意味で幅広い支援を行ってまいりたい と考えております。

そういう意味で本日の座談会では, こだわりの酒造 りを行っておられる蔵元の方々に「新たな日本酒ファ ンを増やすには」というテーマでご議論いただくこと としております。日本酒のグローバル化や地域との連 携あるいは食事とのマリアージュといったことにも参 考となるご意見をいただけるのではないかと思います。

本日の座談会での皆様の意見を汲み上げながら, 更 なる日本酒の振興に向けて全力で幅広く取り組んでま

How to Increase New Sake Lovers

National Tax Agency 
いりたいと考えて扔りますので，どうかよろしく㹉 いいたします。

（田中）ありがとうございました。

それでは，座談会に移らせていただきます。ここか らの進行は国税庁の宇都宮鑑定企画官にお願いしたい と思います。

\section{2 日本酒の飲酒シーンの変化}

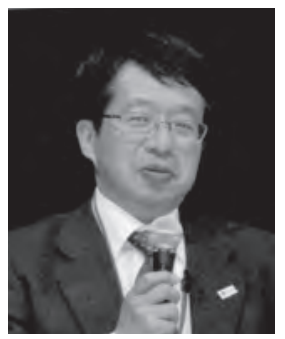

（宇都宮）鑑定企画官の宇都宮 です。本日はご案内のと扔り 「新たな日本酒ファンを増やす には」というテーマで日本酒の 裾野を拡大するために工夫すべ き点や課題についてお話を伺っ てまいりたいと考えております。 宇都宮氏 豪華なメンバーが揃いましたの で，いい討論ができればと思っております。

最初に司会の人に振るのは悪いのですけど, 田中さ んはミス日本酒でいらっしゃいますが，何をきっかけ に日本酒に興味を持ったのかまず教えて下さい。

（田中）私，2 年前に宝くじ幸運の女神をやらせてい ただき 1 年間で 47 都道府県を回りました。その時に 全国の地酒を頂戴いたしまして, 同じ日本酒なのに地 域によってこんなにも味が違うのか，そして同じ地域 なのに造り手さんによってまた日本酒の味が違う。本 当にそこに魅力を感じまして，さらに日本酒の魅力に 取りつかれている次第でございます。

(宇都宮）ありがとうございます。秦さん，日本酒の 飲酒シーンというのもずいぶん変わってきているよう に思うんですけど。

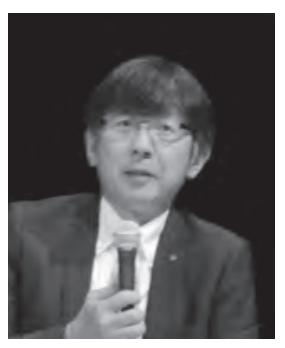

秦氏
(秦)そうですね。ほんとに昔 はお酒を飲みに行く。酒を飲み に行こかということで，お酒が 主役であってあくまでも料理は 脇役であったんですけど，逆に 今は料理が主役でお酒が脇役に なったりしますし，我々が自宅 で飲む場合でも，以前ならば一 升びん 1 本買って 1 週間毎日同じ酒を飲んで, また無 くなったら次の一升びんを開けようかっていう時代だ ったんですけど，今では今日は何かいいことがあった ので吟醸酒飲もうかだとか，今日はいい純米酒を燗酒
で飲もうかとかですね，いろいろな飲酒シーンによっ てお酒もバリエーションが必要で, そういう飲酒ス夕 イルに我々造り手の方も対応していく努力が必要なの かなというふうに考えています。

(宇都宮) 木下さんには大学生の娘さんがいらっしゃ るそうですけど，その方達の飲み方っていうのはどう なんですか。

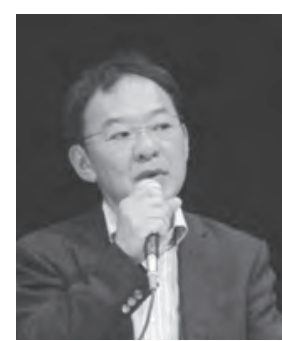

木下氏
（木下）娘が 2 人大学生でござ いまして，あと私も数年前から 九州大学の農学部できき酒とか 発酵に関する講義を年 1 回やら せていただいております。その 時に学生の皆さんと交流いたし ますと，私達が若い時と比べま すと, 酔っぱらうために飲むと いうよりは，仲間内で会話を楽しんで，その一時のた めに飲むというような，そんな飲み方になってきてい るなという感じがします。それと日本酒とりわけ地酒 の純米酒や純米吟醸酒に対する印象が, 例えば 10 年 前に比べて随分よくなってきている。分かりやすく言 うと, 酔っぱらうために毎日のようにガバガバ日本酒 を飲むというようなことはしていないけど，例えば 「宅飲み」と称して誰かの下宿に集まって料理や酒を 持ち寄ってみんなで飲む，そういう時にワインを持っ てくる子もいるけども, 地酒の純米酒一升びんを買っ てくる子もいる。そんな楽しみ方をしている人がじわ じわ増えているようでして, 私は健全な方向に進んで いるのではないかと感じて㧍ります。

(宇都宮) 田中さんも「宅飲み」しますか。 (田中) はい。よく友達としております。「宅飲み」で みんな日本酒を持ち寄って飲むんですけど，まだまだ 若い世代の人達は，どんな日本酒でどういう味がする のかといった深いところは分からないので，これから もっと学んでいきたいという話はしていますね。

(宇都宮) 尾畑さんは中央会の需要振興委員をされて いますが，今年「二十歳からの日本酒イベント」とい うのを開催されたそうですが，そこに来られた若い人 の反応はどういう感じでしょうか。 


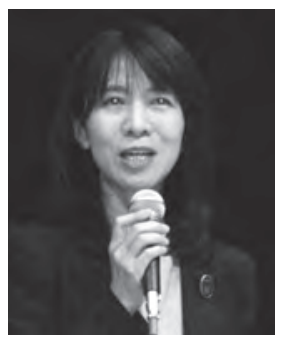

尾畑氏
（尾畑）はい。今年の 1 月に東 京で約 100 名の 20 代の方を募 集しまして，あとDancyu さん にご協力いただきましてイベン 卜を開催いたしました。女性の 方がやっぱり半分以上いらっし やいまして，ただお酒を飲むだ けではなくて, 背景を楽しみた いとか、マリアージュを楽しみたいという方が多かっ たですね。

その様子を見ていて大きく 3 つ感じました。まず, 日本酒のイメージがやはり変わってきているというこ と, 海外情報が逆輸入されているっていうことがある かと思います。2つ目は若い方が扔しゃっていたん ですけども，日本酒は他の拪酒に比べると人をつなぐ ところがいいと。スタッフは 30 代から 60 代くらいま でいたのですけど，扔酒に関していろいろ会話を楽し めるって意味では，世代をつなぐ酒でもあるのかなと いうふうにも感じましたね。3つ目は業界自体の興味 ということがものすごく感じられたことです。「二十 歳の日本酒ブック」という冊子を作ったんですが, 業 界内で約 30 万部の希望がありまして, 通常の冊子に 比べて 3 倍以上の高い関心をいただいたという，その 辺を重く受け止めております。

(宇都宮) その関心というのは，何が一番の要因にな っていると考えられますか。

（尾畑）例えば，10 年前だとまだ二十歳の大学生だと なかなか消費に結びつかないっていうふうに思われて いたかもしれないんですね。若者の日本酒離れってい うことがだいぶ言われていた頃なので。それが今若い 人たちに飲んでもらわなきゃいけないって感じるのは, ある意味危機感でもありますし, 若い人達の日本酒に 対するアクションが変わってきたということを皆さん 肌で感じていて, 業界としてもそれをぐっと後押しし ていかなければいけないと考えているんだと思います。 (宇都宮）尾畑さんのお話の中にマリアージュという 言葉が出たんですけど，実は今田さんのご活躍を SNSで拝見しておりましたら，最近マリアージュや ペアリングについて面白い体験をされたとういう記事 をちょっと見ました。そこをご紹介いただけたらと思 うんですが。

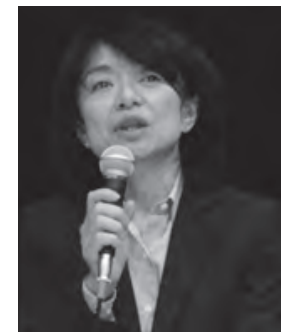

今田氏
（今田）はい。つい先日なんで すが，ペアリングの勉強に知り 合いの編集者が誘ってくれまし て,フレンチのレストランに行 きました。ペアリングっていう のはもともとワインの世界で発 達したものなので, ワインのペ アリングをソムリエさんに教え てもら扮，その扔店はワインだけではなく日本酒も フレンチのコースに合わせて紹介してくださっている 所です。その中で一番の激論になったのは, 私達はど うしてもオフフレーバーっていうのをここ 2,3 年よ く耳にするし，使うんですけども，やっぱりそれは味 のノイズ的なものだからどうしても取ろうとするし， 無くしたいと思って心をくだいて，ほんとに精一杯や っているんです。ただそれは突き詰めちゃうと個性の 無さにつながりかねないようなところがあって，ソム リエさんの考方方としては, そのオフフレーバーがあ ったとしても, 最終的にお料理と着地させる時の満足 というか, お客様の楽しみの総量を増やすような形で お料理とペアリングするのがソムリエの仕事なんだそ うです。だからワインの世界にはマイナスの表現って いうのは非常に少ないというか無いし，そのような考 え方はチェンジした方がいいんじゃないかという，そ こがどうも私の頭の切り替えが難しくって, 個性があ ってもいいんですけども，どこまでが個性でどこから がオフフレーバーで久点なのかというところが, なか なか判断が難しいなと思いました。

（宇都宮）私は先週 IWCの審査に行って，52 名の審 査員がいるんですけど，半分が日本人で半分が海外の 人でして, 主としてワイン業界で働く方, ソムリエの 方もいらっしゃいますし, ワインビジネスをやられて いる方もいらっしゃいます。その中で, 酒が濃いのと ダレているのは違うとか, こいつはオフフレーバーで アウトだけどこれは OK とか, きちんと分かっておら れる海外の方がいまして, だいぶ海外の人も進歩した なと感じました。一方で, この変わっているやつだっ たらうちは大丈夫だからと言う人もいて，いろいろた ったんですけども, やっぱりきちんとワインを見てい る人は, 日本酒に関しても正しい判断ができるなと感 じました。

佐藤さん, 日本酒のオフフレーバーという話ではな 
くて，今酒質が非常に多様化していますし，佐藤さん は特にそういうことで注目もされていると思うんです けど，何かございますか。

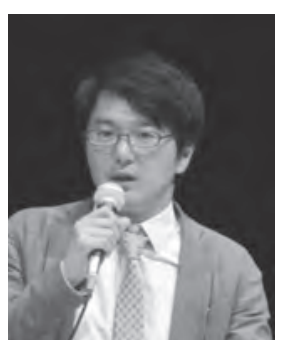

佐藤氏
（佐藤）市場もすごく多様化し てきたというんですか, アルコ ールが低い㧍酒もでてきたりし て，すばらしいなと思うんです けど，我々の蔵も 7,8 年くら い前からいろいろやっていまし て，ちょっと一貫性がないよう に見えるんですけども，実はい ろいろ考えてやっています。

前から思っていたんですけど，今，日本酒がすごく 人気ですけども，基本的にこれは純米吟醸のブームだ と思っているんですよね。焼酎も結局は芋ブームだっ たわけで，日本酒は純米吟醇ブームだと思っているん ですが，吟醸っていうのは 100 年くらい前から先人が こつこつリスクを背負って作り上げてきたものなんで すね。富久長さんゆかりの三浦仙三郎さんとか，うち の曾祖父さんは 6 号酵母を介して貢献していますし, 純米は重くて飲めないと言われましたが, 神亀さんと かがこつこつやってこられて，それが時間を経て融合 して純米吟醸になっているんですけど，ここで伝家の 宝刀がもうすでに抜かれていまして，次に何があるの かと 7,8 年前から思っています。歴史を見ると, 江 戸時代から目まぐるしく技術も味も変わっているんで すけど，非常に品質は高くなっているけども，方向性 としては画一化してきているのかなというのがあって， 今, 全商品生もと造りにしたり, 木桶にしたりとかで すね，酒質競争からは若干降りるようなことになって， リスクをはらむんですけども，やはり我々が先人の力 で純米吟醸で食えているので, 何か後世のためにもで すね，新しい種を残すべきだろうと思っていろいろや っているんですが，それを傍から見るととっ散らかっ たもののように見えるんですが，基本的にはそういう つもりでやっていまして，最近ほんとに面白い酒が出 てきているので, 行き先は明るいんじゃないかという 気持ちを抱いております。

（宇都宮）居酒屋にいってですね、ジューシーな酒を くれと言っている人を見て, 今まで我々の用語に酒に ジューシーという用語はないと思っていたんですけど も,フレッシュでフルーティーいわゆるジューシーと
いうお酒が増えてきたと思うんです。そこに，それば つかりではいけないということで，佐藤さんとかはい ろいろ取り組まれているんだと思いますが，一方で, 日本酒は温度を変えると味わいが変化して楽しめる酒 であるということを言って，業界でもそれを PRして いるんですけど，今年の 2 月号の料飲雑誌で全てがお 燗特集ということもあったんですが，㧍憪の魅力って いうのは今後どのように PR できるでしょうか。 (木下) 福岡県酒造組合で「㧍酒の学校」っていうの を 10 数年やりまして, 約 300 名の卒業生を出したん です。その時にお燗っていうのは講義の中でも重要な テーマだったんですね。抒閒するということは手間を かけるということ，そもそもサービス側も手間をかけ る，そして盃のやりとりが実は単に酒を注ぎ合ってい るのではなくて，そこで心のやり取りをしているんだ, 気持ちのやり取りをしているんだ，これが最も大きな お閒の魅力ではないかっていう，僕らはその学校を通 じて結論に達したんですね。この学校を始めた頃にで すね，それは女性を対象に始めたんですけども，上司 が無理やり盃をよこすと, それはパワハラで, 嫌で嫌 で耐えられないという生徒さんがたくさんいたんです よ。そういう側面もあるかもしれないけど，違うよと， どれだけの手間がかかってその㧍憪の㧍酒を楽しめる っていうのか，それを一歩踏み込めば，はるかに楽し い場にそこが変わると思います。温度を変えることに よる味っていうのも，もちろん大事です。だけど拪酒 は誰と飲むかによって一番，まずいか，うまいか変わ ると僕は思っているんですよ。誰と飲むのか, どんな 雲囲気で飲むのか, そしてその次に料理があって, そ れを考えた時に，お憪はすばらしい場を作る一助にな る，私はそういうふうに思って扔ります。

(宇都宮) はい。いい人と飲むということと, 誰かが 勉強的に教えるのではなく，こういういいものだよと いうようなことを教えることが重要だという話だった んですけども，秦さんから何かございますでしょうか。 (秦) 先ほどの木下さんの括しのように，打酒とい うものは唒だけではなくて, 飲酒スタイルも含めた 文化だと思うんですよね。そういう幅広い情報をどう やって伝えていくか, それはいい大人との出会いだと 思います。今, 大学の生徒さんがいい拪酒を飲んでい るという話がありましたけれども, 大学の教授の先生 がお酒に親和性がないと中々伝わらない。先生がお酒 
が好きで，いろんなお酒の情報を持っておられるとい う生徒さんは, 非常にいい出会いがあって, お酒のこ とをよくご存知だと思います。伝える情報量が多いが 故に，できるだけいい大人と出会って情報を獲得して 欲しいなという気持ちです。

(宇都宮)いいお酒が造られるようになったというこ ともありますけれども，やはり，業界として「お酒テ ラピー」や「お酒の学校」とかを 10 年以上続けてき たということが，今日，日本酒が盛り返してきたこと の一助となっているんじゃないかと思います。

\section{3 日本酒と食とのマリアージュ}

（宇都宮）ここでまたマリアージュとか食との相性の 話に戻るんですけども，先週ちょうどIWCの前に JETRO のセミナーがあって, そこで田崎真也さんが ソムリエの立場から見た日本酒の拈話をしていたんで すけども, 結構衝撃的な話をしておりましてですね, もともと日本酒は食中酒なのかっていう話をされて, 僕は目から鱗が落ちました。もともと塩辛ですとか, 枝豆，煮物とかでちょこっと飲んでいて，さあ，扮 さんお食事にしますとか，宴会の時でもこれからお食 事にしますということで，そこまでは酒のつまみであ ってですね，ほんとうの食事なのかっていうような話 をされていて，ちょっと衝撃を受けました。また，今， 銘酒居酒屋とかに行っても結構打酒だけを飲んでいて, 次何飲もうかというような人が多いんですけど，そう いったサービスも含めて，佐藤さん，扔酒と料理の相
性についてどのようにお考えでしょうか。

(佐藤) 食中酒ってよく言われるんですけども，2夕 イプあって，どんな料理にも合う食中酒もありますし， どちらかというと特定の食べ物, 〈せはあるんだけど 特定の食べ物と合わせた時においしいという 2 タイプ あると思うんですよね。ワインでもイタリアのワイン とかはどちらかというと食べ物を選ばない気がするし， フランスのワインだとちょっと気難しい気がするし， うちみたいな感じだとですね, 地方の小さな蔵として 個性的な酒を出していきたいということで，どんな料 理にも合うような拪っていうものは造っていなくて, それで飲食店さんにも怒られることがあるんですが, どちらも市場にあってしかるべきだと思うんですよね。 (宇都宮）尾畑さん，何かとがった酒がこのものにす ごく合って見直したとかそういうのございますか。 （尾畑）自社の話ですが，日本酒度プラス 20 以上でな ければ出荷しませんという超辛口の唒がありまして， これが予約で全て売り切れというような，ちょっとマ ニアックな拪なんですよね。考えてみると伝えるも のがある拪っていうことに酒っ客様は魅力を感じてい らっしゃるのかなって思うんですよ。何にでも合うっ ていうのは何にでも合うで終わってしまうんですけど も，おいしさを伝える言葉がいろいろあればあるほど, それをまた人に伝えてその人が拈いしさを感じるとい うことになりますから，そうやって考えると日本酒っ ていうのは，扣いしさを伝えるボキャブラリーがとて も少なくて貧困で，これはここにいらっしゃる方皆さ

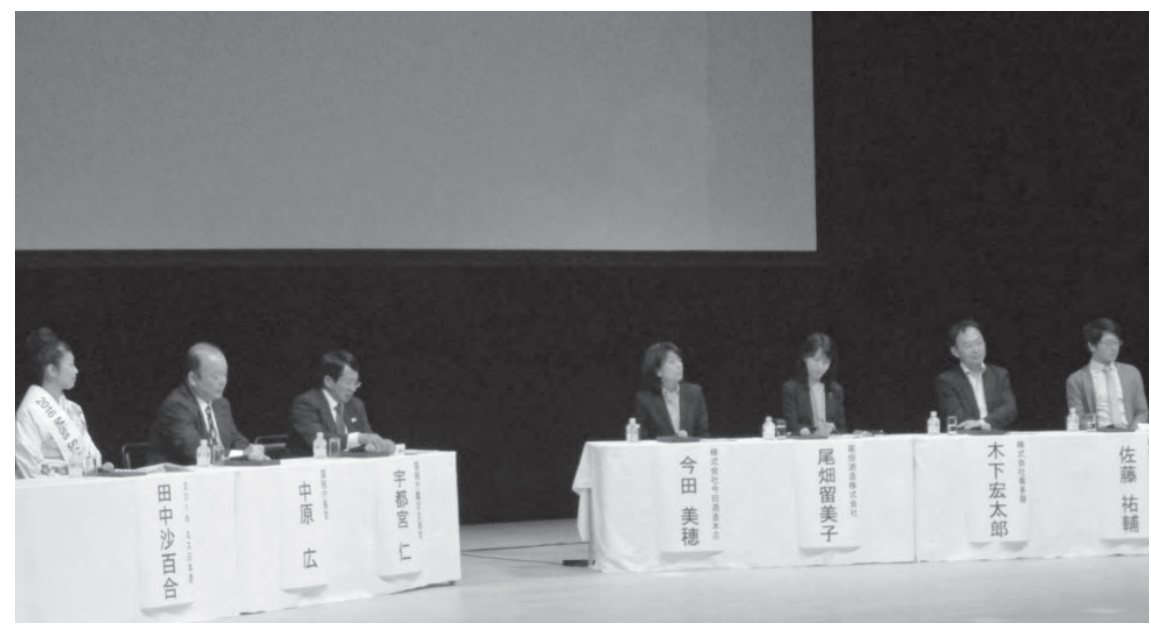

日本酒座談会会場風景 
んお感じになっているかと思います。そういう意味で は，新しい飲み手を育てるっていう意味合いにおいて， いかに日本酒の拈いしさを伝えるかってことを，そう いうツールというか味わい表現を進化させることや料 理のマリアージュも含めて，これからもうちょっと力 を入れていければなと思います。

(宇都宮) 今田さんはこれまでイベントで何か驚いた ことってありますか。

（今田）実は去年なんですけども，地元の牡蠣に合う お酒というのを造ってみまして，それはある酒販店さ ん, もともとは飲食店さんの発案だったんですけど, これから日本酒を飲んでみたいという方に最初に酵母 とか米の話をするのではなく，お料理から広がるマー ケットを作りたいということで，そういう拪を造っ てみました。やっぱり何となく合うというよりも,こ のお料理とお酒がピッタリ合ったっていう，その経験 っていうのは, 割とショックとして大きいというか楽 しみを生む力が大きいという気がします。

(宇都宮) そうですね。私が一番驚いた経験っていう のは, 無濾過生原酒で我々の言葉で言うとイソバレル アルデヒドっていう目にツーンとするような刺激臭が 強いお酒で結構甘いっていうのが出てきて, それを松 本で飲んだんですけど，一緒にですね，山賊焼きって いうすごくニンニク奨油味が強い揚げ物が出てきたん ですよね。それはお酒を単独で飲む時よりずっと素晴 らしくて, 無濾過生原酒ってこういうやつに合うんだ なっていうのが非常に驚きに感じたんですけども，ま だまだそういう知られてないものを発掘できる可能性 っていうのがたくさんあるし，それには製造者だけで はなくて、サービスの人を巻き込んでいろいろやって いかないといけないのかなと思いました。また，いい 日本酒の飲み方を先輩が伝えるということも非常に重 要なことかなというふうに感じました。

\section{4 魅力のある日本酒・酒蔵, 地域との連携, 蔵 の理念}

（宇都宮）一方で, 輸出の話になりますが, 輸出は過 去最高となり, 海外でも日本料理店以外のチャンネル で受け入れられるようになりました。日本酒はワイン に競合するものではなく，ワインリストを広げる商品 として興味を持つディストリビューターも増えている というふうに聞いております。彼らにとって魅力のあ
る日本酒または魅力のある造り手, 蔵のストーリーや 理念について少し扮伺いしたいと思います。

今田さん, 海外で自分の蔵の何を PR しているのか を教えていただきたいんですが。

（今田）私の場合はですね, まず広島安芸津というと ころにありまして, 何しろ軟水で初めて拪酒を造った という歴史があるものですから，まずその広島杜氏と か酒の歴史の話をします。それから吟醉っていう言葉 を覚えて下さいというのがまず1つなんですけど，吟

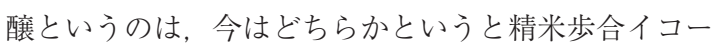
ルみたいなことになっていますけど，もともとそうじ やなかった。やはり, 吟味して丁寧に造るっていう, 数字とは違う造りの哲学みたいなことを含んでいる言 葉なんですということを括しすることが多いですね。 (宇都宮)いわゆるスペックというか仕様みたいな話 を，うちのやつは何％ですとか言うんですけども, 向こうの人にはよく分からない言い方があったり, 30\%とかラベルに書いてあると，アルコール分が 30\%なのかと驚かれるようなシーンもあるというふ うに聞いております。

木下さん, 実際に海外で営業されていると思います が，そこではどのようにPRしていますか。

（木下）私は約 20 年前, 1996 年からだからちょうど まる 20 年ですね, 20 年前にアメリカから海外輸出を 始めました。その後の 10 年間というのは伸びました けど，ほんとにこつこつじわじわくらい。自分自身で 営業に行くようになって 10 年ぐらい, 私自身造り手 なので冬場はまず出ることはありませんので, この暖 かくなってから秋までの間ぐらいは，ほぼ毎月どこか の国に行っているような状況です。 3 年前に IWCで チャンピオンを頂いてからの伸びが大きくて, その前 は8 8 国くらいだったのが, 今は 15 力国, この後 2 カ国今年中に新たな取引が始まります。 3 年前と今で は海外の出荷は 3 倍以上くらいになったでしょうか。 今, 生産量の $8.5 \%$ くらいを海外に出しているんです けども, まだまだ伸びるなと, 自分で海外に行ってと ても強く感じています。

海外に行くとファミリービジネスで 100 年, 200 年 と長く続いていることが, お酒に限らずとても尊敬さ れます。アメリカでもヨーロッパでもアジアでも，私 たち中国って言うと中国 4 千年の歴史とかよく枕詞み たいに使いますけど, 香港でもだいたい 2 代目経営者 
ですよね。3 代目になっていたら世代交代が早いぐら いで，中国なんかだと初代ファウンダーみたいな人達 が多い。だから歴史があること，味を含めて受け継い でいる，文化を受け継いでいるということに対してと ても大きな賞賛がある。そこにおいて規模の大きい, 小さいというのはあまり重要ではなくて，その中でど んな理念で続いてきたのかということがその次に聞か れますよね。

私の会社の場合で言うと，そもそも 200 年前に初代 が創業した時に，お酒を通してたくさんの皆様と喜び を共有するような酒造りがしたいという想い，たくさ んの喜びをつくる蔵ということで「喜多屋」って名付 けたんですよね。そういうことを拙い英語で話します と，気持ちがよく伝わりますね。

それともう1つはやっぱり海外では基本的にワイン を学んだ上で日本酒に入ってこられるユーザーがほと んどですから，よく言われるテロワール的なこと，先 ほど今田さんもおっしゃいましたけど，私も常に言う のは, 福岡の酒米を使っているんだということ, 山田 錦にしてもですね。それと福岡の食文化，海の幸があ り，山の幸があり，焼き鳥の文化があり，豚骨ラーメ ンがあり，そういう食との関連，その福岡の食を一番 盛りたてるような酒造りを目指してきたみたいな。こ ういうことを話しますとやっぱりすっと受け入れてい ただきます。最終的にはインバウンドに跳ね返えらせ たいので，海外で飲んで下さった方が日本旅行したい と思っていただく。日本旅行するなら喜多屋の酒を飲 んだことあるから福岡まで足延ばして蔵見学をしてみ ようか, この地域をみてみようか, こういうふうな流 れになって欲しいなっていうのが念願です。

(宇都宮) 九州にも韓国とか台湾から酒蔵巡りの方が いらっしゃるというふうに聞いておるんですが，特に 京都はたくさん観光客が来られるんじゃないかなと思 うんですが，そこにおける傾向みたいなものはありま すか。

（秦）そうですね。ほんとに京都は外国の方がたくさ ん来られるところで, うちも博物館という記念館があ るんですけども，そこは年間 10 万人くらい怙客さん が来て, そのうち 3 割くらいが海外の方, 非常に海外 比率が高まっています。大きく分けて東アジア系の方 と欧米系の方がいらっしゃるんですけども，だいたい 東アジア系の方は観光旅行というスタンスですから,
名所巡りをしてそのまま帰っていくということが多い んですけども, 欧米の方は日本のカルチャーに非常に 興味がありますから，例えば年表をずっと見続けると か，酒の道具に興味があって，これは何に使うんだっ ていうことを真剣に聞いてくるとか, そういう部分で 実は酒造りにもいろんなコンテンツとして海外から見 れば魅力のあるものがたくさんあるんですけども，日 本人自身が気付いてない点を海外の皆様から教えても らっている，日本酒造りを含めた日本酒のよさを再認 識するいい機会になっていると思います。

(宇都宮）ありがとうございました。先ほど田中さん にNASA のイベントにも出られたという話を抢伺い したんですけど，NASAのイベントでは何が受けて いるんでしょうか。

（田中）先月アメリカのコロラド州コロラドスプリン グスの NASA で, 全世界の宇宙関係者が集まりまし て，スペースシンポジウムというのがありました。そ こで日本から JAXA と JETRO が一緒になってブー スを出しまして, 海外のお客様に檜の妌に入った日本 酒を拈もてなしするということで, 500 個限定で用意 させていただきました。そしたら 1,000 人以上の列が ズラーっとできまして，あっという間に日本酒が無く なったんですね。やっぱり今, 海外から日本酒はとて も注目されているなとその場ですぐ分かりました。 （宇都宮）ちなみにその妌にはNASA とかJAXA と かって焼き印が入っているんでしょうか。

（田中）NASA，JAXA，JAPAN と入っていました。 (宇都宮) それはちょっと1つ欲しいような気がしま すね(笑)。

先ほどテロワールというような話が出てまいりまし たので，少しそういう話にいってみたいと思うんです けど，世界の流れを見てみますと，ビールではクラフ トビールという流れがあって, 昨年, 中田英寿さんが 六本木でプロデュースされたクラフト・サケ・ウィー クというイベントからクラフト・サケという名前も認 知されてきたように思います。ワインでもブティック ワイナリーという小規模でコンセプトの統一されたワ イナリーというのが注目を集めていると思います。こ れら大きく分けて地域のこだわり，テロワールに関す るこだわりを行うものと, 厳選された原材料は使うん だけど，レシピとか製法とか造り手にこだわるところ があろうかと思うんですが，尾畑さんのところは佐渡 
という地元にこだわっていろいろされているのでお話 を伺えればと思います。

（尾畑）はい。当社も2003 年から輸出を始めまして, 今は 14 力国, 15 地域やっているんですけども, 当初 はスペックばかりを語っていて，なかなか味が伝わら ないというところで苦しんで，はたとやっとその地域 性という個性を伝えるべきだということに気付いた次 第です。

お酒っていうのは地域を伝えるツールで，であれば そのお酒に佐渡のコンテンツをいっぱい詰め込みたい と, そう思いまして, 当社が今, 主に使っているお米 の一つに越淡麗というのがあるんですが，佐渡島は，

朱鴊が飛んでいる環境に大変配慮した島ですので, そ の環境配慮型の作りで「朱路と暮らす郷づくり認証 米」という制度に則って作っております。

さらに契約農家さんの工夫で牡蠣殼農法を取り入れ ています。佐渡は牡蠇が有名なんですが，その牡蠣款 を使ってミネラルたっぷりな水を田んぼに引いて, す ごく健康に育つ酒米を使ってお酒を仕込むということ をやっています。

そういうふうに地域性にこだわっていったら，もっ と地域を元気にしなくちゃっていう想いも出てきまし て, 2014 年からは佐渡島にある廃校を仕込み蔵に再 生させた「学校蔵プロジェクト」というのも始めまし た。ここでは, オール佐渡産の酒造りというのを目指 していまして, 酒米はもちろんなんですが酒造りに使 うエネルギーも佐渡産ということで，今，島の太陽か ら酒造りのエネルギーを $40 \%$ ほど導入しています。 最終的には $100 \%$ を目指していきたいなと考えている ところです。ここでワークショップなどもやっている んですけども, 日本酒が核になって地域の人だけでな くて, 地域の外からも佐渡島に訪ねてきてイベントな んかを一緒にするようになりまして，そうすると化学 反応が起きまして，また地域の未来づくりに貢献する ような人材が育っていくという，捛酒だけじゃなくて そういう人材に関してもいい循環を生んでいくんだな ということを感じ始めています。要するに, 日本酒造 りというのは地域づくりなんだということです。ほん とに地域が元気でないとお米ができないし, 環境がよ くなかったらいい水もないし, 飲んでくれる人達がい なかったら拪も売れないし，そもそも飲んでくれる 人が少なくなるのも切ないものなんですけども，捛酒
を造っている地域から人がどんどんいなくなるってこ とはもっと切ないんですよね。そういう意味ではうち だけではなくて，いろんな蔵元さんがそれぞれの地域 でたくさんの活動をしているっていうのは, きっと同 じ想いからなのかなと思います。

(宇都宮) 今田さんのところは古いお米の復活をされ たということなんですけども，ちょっと聞かせていた だけますか。

（今田）はい。八反草といいまして，今の八反錦の親 になるお米なんですが, その前は山田錦を地元の人達 と作ったりしていたんですが，広島県が山田錦を作る ということになり，その年にちょうど八反草の種籾を ジーンバンクの人が出してくれることになりまして, 今それを一生懸命やっています。

将来，地域のこととかを考えた場合に，まだまだう ちもこれからなんですけども, 田んぼとどれくらい近 いところで時間を積み重ねてきたか， みたいなことが 自分の蔵の将来にとっては大切になっていくような気 がしていて, この八反草でできた人間関係とか, 農家 さんとのつながりを広げていくというのが, 今の私の 宿題です。

(宇都宮) 木下さんのところは, 福岡県としてもいろ いろやって扔られすし，木下さんのところもやって おられますよね。

（木下）ご存知のとおり福岡は平野に恵まれています ので, 稲作としては恵まれていると思います。福岡県 酒造組合とそれから JA 系島っていうんですけども, 福岡から唐津に向かう途中にある半島のところ, ここ で山田錦の作付けが始まったのが昭和 26 年かな, が っちり長年組んで私たちのはるか先輩の時代からそう いうことをやってきています。ただですね, 山田錦は 県北で作っていまして, 私の蔵があるのは県南なもの ですから, 蔵の周りでというと酒造好適米の生産実績 がそしかったんで, 1998 年に会社内に「喜多屋米作 り委員会」をつくって, 自分達も田んぼに入って米作 りを学ぶということを始めて, 地元の JA 八女と組ん でいろんな米を作ったんですけど, 国の研究機関の九 州沖縄農業研究センターが開発した山田錦の血筋を 4 分の 3 引いていて短秙にした「吟のさと」という品種 にめぐり合いまして, めぐり合った時にはまだ産地品 種登録も当然なかったし, 開発コードしかなかったん ですけども，それを自分のところの田で作って，試験 
醉造して，それを地元の農家の人にお願いして，最初 自社田以外の農家の方は 1 件だったのが，ずっと増え て, 今 24 人プラス 1 農業法人という形でやっと地元 の乾燥用カントリーエレベーターのサイロ 1 本分, 約 30 ヘクタール強くらい作付できました。今年もさら に数％増やす予定なんですけども，もちろんうちが 1 社で使うのではなくて, 地元県南の蔵で分けて使う 予定です。 2 日前もその人達と今年のキックオフをや って, 懇親会では 12 時過ぎてへろへろになるまで飲 んでいました。とても盛り上がっています。

（宇都宮）ありがとうございます。佐藤さんのところ は業界的には, すごく斬新な造りとか, レシピとかと いうことで皆さん注目されているんですけども, 佐藤 さん自身のクラフトとかテロワールに関する技考え, 方針があれば教えて下さい。

（佐藤）そうですね，今月の 20 日に新政農業生産株式 会社っていう農業生産法人をつくって, やっとそちら の方も頑張れるようになったんですけども，基本的に 例えば，原材料が無農薬とかでも受入側の製造工程で それに見合ったものでないといけないので, やっぱり 製造工程の見直しの方が先でした。でも，これは先ほ ど申し上げたとおりブランドの多様化とかとも関連し ていて，私としては伝統産業とかに還ることによって クラフト的なとこを強めていって, それからテロワー ルがついてくるというような考え方でした。日本酒の 歴史を見てみると, 明治を境にして造り方がガラッと 変わっちゃったっていうか, 江戸より前は体験集積型 みたいな感じで酒造りをしていたんですけども，明治 維新で酒税が導入されて, 我々蔵元たちも保護産業と なって, 技術の開発主体がやっぱり蔵じゃなくて公的 機関とかになったんですよね。それからその流れがず っときていて, この発想法っていうのは西洋科学で特 にビールからきているんですよね。科学は汎用的なも のだから，どこかの蔵に1つ1つオーダーメードで作 られたものではなくって, 月桂冠さんとかは研究所と か持ってらっしゃるので自分にあった科学技術を使え ると思うんですけども, 中小零細企業蔵だ科学技術 をべースとした酒造りだと, 県の醸造試験場とかに頼 らなきゃいけなくなってくる。そうするとやっぱり市 場を見るとだいたいみんな同じ酵母で, 同じ趓菌使っ て，醴酵方法とか粪歩合とかもだいたい同じで，あと 高級酒は山田錦でとかですね，だいたい規格化された
ものになってきちゃうんですよね。構造上しょうがな いことなんですよね。今後この業界的にどうしたらい いのかなと思った時に, 参考にするのは科学以前の製 法ですよね。明治以降は優生主義というか科学なんで, ここの成分がよければすごく増やす。この成分ダメだ と無くすとかそういう感じなんですけども, 昔の造り はもう少しホリスティック全体主義というか全体思想 的というか, この成分はいいところもあるし, 悪いと ころもある。だけど全体としていいから，それでいい といった造り方でして, そっちの方が個々の蔵の個性 はでるのかなと思っています。そういうことで多様化 とクラフト化を同時に推進するには, 伝統的な技法は 欠かせないのかなと思ってですね, 途中でそれに気付 いてだんだんやってきた気がします。それにテロワー ルとかも入ってくると国際的に見ても魅力的なものに 成り得るんじゃないかなと, このあたりは日本酒の先 としてもいい方向なのかなと, 科学が悪いと言ってい るんじゃなくて, これがどちらも共存して, 科学のお かげで日本酒の品質が底上げされているのは事実なの で, 二つ揃って未来の日本酒かなっていう気がいたし ます。

（宇都宮）日本酒はそれこそ室町時代に骨格ができて， ざっと 400 年以上の蓄積があるんですけど, 種はそう いうところに転がっているというような感じなんです かね。全く新しいことではなくて, 古いところからも 種を探しながら，自分の考えに合うものを選んでいく というのが今の佐藤さんの㧍考えですね。ありがとう ございます。

酒類総研とともに非常に科学技術の長い歴史を誇る 月桂冠の秦さんに, どのように会社として研究開発に 取り組んできたのか, ちょっとご紹介いただけたらと 思います。

(秦) 私, 今研究所長というのをしているんですけど も, 研究所ができましたのは 1909 年, 今から 107 年 前にできました。今では企業に研究所があるっていう のはそう珍しいことではないですけども，やはり 100 年以上前にですね, 酒蔵に研究所を建てるっていうこ とは非常に勇気もいりましたし、これからは科学技術, 理屈で解明する酒造りをしょうというオーナーさんの スピリッッは今でも感じています。ただ佐藤さんがお つしゃったようにですね, 研究開発で酒を造るわけで はなくて，あくまでも研究開発でできた理論を人間が 
どうやって扱うかっていうのが大事で, 数字だけに振 り回されることがないようにはしたいと思っています。 先ほど少し多様化とかオフフレーバーの話がでてき ましたけれども，今日は技術者の人が拈集りなのでち よっと一言括話しさせていただきますと, オフフレー バーとか悪いものは製造過程上のミスで起こることが 多いんで, どうしても技術屋としてはあるいは造り手 側としては敏感になってしまうんですよね。そういう ものを見つけると鬼の首でも取ったかのようにですね， こういう悪い香りがあるとついつい言ってしまいたい という, 品質管理上そういうアンテナは必要なんです けども,やはりその一つの多様性といった広がりを狭 めているということも事実なので, 研究開発技術と並 行して人間の感性も入れながらやっていきたいと思い ます。

(宇都宮) ありがとうございます。こちらの方々は皆 さん 100 年以上の歴史を誇る蔵の方なんですけども, 例えば家訓とかこういった言葉が残されているとかあ りましたら最後にご紹介いただきたいんですけども， 今田さんのところは。

（今田）うちはですね，「百試千改」でございます。百 回試して千回改めるという情熱と覚悟で酒を造りなさ いという広島杜氏に伝わる言葉です。

(宇都宮) ありがとうございます。尾畑さんのところ は。

(尾畑) 二つありまして，一つが「四宝和䁔」で四つ の宝の和をもって醇すという酒の三大要素, 米, 水,

人に加えて生産地の佐渡, この四つの宝という意味で す。もう一つが「幸醸心」で, さっきの学校蔵の校訓 なんですけど，いわゆる向上心を持つというのにかけ て幸せを醸す心，これが当社の理念です。

(宇都宮) それでは木下さん是非抒願いします。

（木下）うちにとって最も大事なのは, 先ほど申し上 げた屋号に込められた理念なんですけど，それを実現 するためのその次に大事なものとして, 家訓じゃなく て家憲, 家の憲法と初代が定めたものがありまして,

「主人自ら酒造るべし」なんですよ。200 年前の封建 時代に拝いて初代は杜氏をやって, そういう形で私の 7 代目までつないできているんですよね。当然スーツ を着ていることはほぼ無くて, 会社にいる限り蔵人と 同じ作業服です。だから私の顔を知らない人は，あの 人が社長だって分からないんですけども，そんな中で
大学でバイオ学んで, 月桂冠さんじゃないもう一つ京 都の大きい蔵で酒造りやったんですが, その後, 国税 庁醸造試験場時代に平成 2 年 4 月から 2 年 3 力月, 岩 野君夫先生が室長された第 5 研究室でお世話になりま した。もちろんその後, 今につながる新しい技術って いうのは, いっぱい開発されていますけど, 一番根本 的なことはその 2 年 3 カ月で教えてもらったと思って おりまして，そこにいなかったら今のうちの会社の状 態にはなっていないだろうと思っていますので, 決し て足を向けて寝られない存在, もち万ん独法になって 以降もですが, そういう意味でとても今後の酒類総研 の発展と研究に期待しております。

(宇都宮) なんかここでまとめてもらったんで，ここ で締めようかと思ったんですけども, せっかくですか ら佐藤さんのところも 6 号酵母発祥の地というか, 秋 田の酒屋さんをリードしながらずっと前からやられて いたということで, 家訓でなくても取組に対する姿勢 などありましたらお願いします。

（佐藤）家訓は無いんですけども，6号酵母発見時の 当主の曾祖父さんが, 死ぬ前に「酒造りは信仰の問題 である」と言ったんですよね。重くてですね，意味が 分からないんですけども, 曾祖父さんは結構科学技術 的な造りもきちっとやった方なんですけど, 同時にそ ういうものも持っていたんだなと思いまして，ちょっ と意味がよく分かんなくて, やたらと信心深くなりま して, 先週も農業生産法人の設立の日に出雲大社に行 ってお参りしたりとかですね,いっぱい神社に行くよ うになりましたね。

(宇都宮) なかなか全部割り切って, 皆さん技術者で すから自分で酒を造っていると分かると思うんですけ ど，全てが自分の思うと抒りにいかないですよね。毎 年造りは違うんだというのは, 米の状態とかも違うん だろうけど，ほんとに上手くいかないことっていうの もあろうかと思います。そういうところで気を引き締 めるとか、いざとなったらそういうところに頼るとか いうようなことかもしれません。

\section{5 結びに}

（宇都宮）ちょうど話が盛り上がったところで切るの は心苦しいんですけど，今までの括話を聞いて中原長 官なにかございますでしょうか。

(中原) 素人の勝手な印象論というところで, 非常に 
印象に残ったところを何点か申し上げます。

一つは最初に日本酒の魅力, それは地酒の多様性で あるというところから話が始まったわけでありますけ ども，日本酒の魅力というのは突き詰めていくと，多 様性であり個性だということなんだろうと思いますが, 議論の中で例えば純米吟醸だけがヒットしているんじ やないかというような，大きく見たときに画一的にな りがちだという懸念のご披露があったのが一つ非常に 印象的でした。

それから若者にどう酒を教えていくか, 二十歳のお 酒デビューの話がありましたけれども，その中でお酒 というのは結局, 誰と, どこで, どういう雲囲気で, 何を食べながら，そういうのが大事なんだという括 がありまして, 全く同感いたしました。やはりしみじ みと飲むのか, むっつりと飲むのか，あるいはあまり よろしくない飲み方ですけども, 我々サラリーマンの ように上司の悪口を言いながら飲むのか，あるいは以 心伝心の人と黙って飲むのか, そういう酒を飲むシー ンをイメージできるような広報の仕方が大事であり， それが括話の中であった，いい大人と出会う，あるい は酒が文化であるということなのかなという印象がご ざいました。
それから海外への売り方の話の中でスペック的なも のよりもストーリー性だという括がありまして, こ れもそうだなと感心いたしました。やはりストーリー というのは，歴史であり哲学でありテロワールであり さらに言えば原料へのこだわりであり製法へのこだわ りだろうと思いますが, そういう点はこれからさらな る国内での日本酒消費を考えていく時にも非常に重要 なものではないかと，ですから是非そこは今後とも新 しいストーリーづくり, 外に向かっての発信の仕方,

それを是非進めていただきたいと思います。

それと，どなたかの括にありましたけれども，消 費者の楽しみの総量が増えるようにというのは全くそ のと抢りだと思います。もちろんお酒の品質というか 味というか要するにおいしさが重要なわけですけども, 嗜好品でございますのでそれだけではない，結局どう いうシーンでどういう気分で飲むかっていうのが大事 ですので，そこも視野に入れなくちゃいけないんだと いう印象を受けました。

私ども行政の立場もそういう点をしっかりと頭に入 れて勉強してまいりたいと思います。ありがとうござ いました。
執筆者紹介 (順不同·敬称略)

上田隆穂 $<$ Takaho UEDA $>$

昭和 28 年 12 月 12 日生まれ<勤務先と所在地 $>$ 学校 法人学習院 干 171-8588 豊島区目白 1-5-1 学習院大学 経済学部<略歴>学習院大学経済学部教授。博士（経 営学)。学習院マネジメント・スクール所長を兼任。

(株) 東燃を経て一橋大学大学院に進み, 昭和 61 年学 習院大学経済学部専任講師, 助教授を経て平成 4 年, 同教授。専攻はマーケティング, 価格戦略, セール ス・プロモーション開発, 消費者深層心理, 小売戦略, 地域活性化。主な書籍は, 『生活者視点で変わる小売 業の未来〜希望が買う気を呼び起こす商圈マネジメン
トの重要性〜』（宣伝会議 平成 28 年), 『Visionary Pricing: Reflections and Advances in Honor of Dan Nimer, Volume 19 of the Advances in Business Marketing \& Purchasing series』(Emerald Books 平成 24 年 共著), 『買い物客はそのキーワードで手を伸 ばす』(ダイヤモンド社 平成 23 年 共編著), 『日本 一わかりやすい価格決定戦略』(明日香 平成 17 年) など多数。＼cjkstart抱負＞酒類に関する歴史・文化の普及活 動を通じたマーケティングを促進してみたい。く趣 味>テニス, サイクリング, スキー, 映画, 旅行, お 酒全般 